\title{
Endothelin Messenger RNA and Receptors Are Differentially Expressed in Cultured Human Breast Epithelial and Stromal Cells
}

Patrica A. Baley, Therese J. Resink, Urs Eppenberger, and Alfred W. A. Hahn

Department of Research, Basel University Hospital, CH-4031, Basel, Switzerland

\begin{abstract}
Paracrine regulation is implicit in the biosynthesis and secretion of milk in the breast. An important determinant for this regulation in vivo is proximate cellular location as exemplified by stromal and epithelial cells in breast tissue. Cultured human breast epithelial cells exhibited low constitutive expression of mRNA for endothelin which was enhanced 20-fold after prolactin stimulation. Human breast stromal cells did not express measurable levels of endothelin mRNA under similar conditions. In a similar differential manner, the stimulated release of immunoreactive endothelin into medium overlay was observed only for breast epithelial and not stromal cells. Specific cellsurface receptors for endothelin and biochemical responsiveness to the peptide were observed only in the stromal cells. ( $J$. Clin. Invest. 1990. 85:1320-1323.) breast tissue • endothelin expression • endothelin receptors
\end{abstract}

\section{Introduction}

Endothelin (ET) $)^{1}$ is a recently discovered 21 amino acid peptide that was first isolated from the supernatant fraction of cultured endothelial cells and found to have potent vasoactive properties (1). Constitutive expression of ET mRNA has thus far only been found in endothelial cells, whereas specific receptors for, and physiological responses to ET have been demonstrated both in vivo and in vitro for a variety of tissues both within and outside of the cardiovascular system (2). Therefore, important issues are whether endothelial cells are the only source of ET and whether ET acts as a paracrine factor. We have approached these issues by investigating ET mRNA and receptor expression in breast epithelial and stromal cells (BEP and BST, respectively). Their proximate location in mammary tissue represents a structural correlate to endothelial and smooth muscle cells in the vasculature, and furthermore the

Address correspondence to Dr. Alfred W. A. Hahn, Department of Research, Basel University Hospital, CH-4031 Basel, Switzerland.

Received for publication 20 November 1989 and in revised form.

1. Abbreviations used in this paper: BEP, breast epithelial cells; BST, breast stromal cells; EGF, epidermal growth factor; ET, endothelin; $h$, human; IP, inositol phosphate; $\mathrm{IP}_{2}$, inositol bisphosphate; $\mathrm{IP}_{3}$, inositol trisphosphate; $\mathrm{TGF}_{\beta}$, transforming growth factor $\beta$.

J. Clin. Invest.

(c) The American Society for Clinical Investigation, Inc.

$0021-9738 / 90 / 04 / 1320 / 04 \$ 2.00$

Volume 85, April 1990, 1320-1323 process of lactation may, in general terms, bear functional analogies to vasoconstriction. We report that constitutive and regulated expression of ET mRNA occurs in BEP but not BST, whereas only the latter exhibit receptor-dependent responses to ET.

\section{Methods}

Cell culture. BST and BEP were isolated from tissue obtained by consent from patients undergoing reductive mammoplasty essentially as described by Petersen and van Deurs (3). Cells were phenotypically characterized by immunocytochemistry using monospecific antibodies against smooth muscle-specific $\alpha$-actin and epithelial-specific cytokeratins and immunoperoxidase staining procedures with the help of, and by the methods described by Petersen and van Deurs (3). All immunoreagents used were obtained from the same sources as described by the latter. Cells were cultured in IMEM-ZO medium which consisted of $20 \%$ (for human [h]BST) or $2 \%$ (for hBEP) FCS; penicillin and streptomycin $(100 \mathrm{U} / \mathrm{ml}$ of each); sodium selenite $(7 \mathrm{ng} / \mathrm{ml})$; hydrocortisone $(500 \mathrm{ng} / \mathrm{ml})$; and insulin $(15 \mu \mathrm{M}$ for hBST, $30 \mu \mathrm{M}$ for hBEP) buffered with $15 \mathrm{mM}$ Hepes, pH 7.3; the epithelial cell media also contained $50 \mu \mathrm{g} / \mathrm{ml}$ heparin. These media were used for all the experimental protocols described below. Differences in the percentage of FCS for both types of cells did not alter the expression of or response to ET.

Preparation of RNA for Northern analysis. After experimentation cell layers were rinsed with PBS and cells lysed with guanidine isothiocyanate buffer. Total cellular RNA for Northern analysis was prepared from control and stimulated cultures maintained in their respective culture medium by procedures described previously (4). Blots were hybridized to random primed ET-specific cDNA (supplied by Dr. Powell, Hoffman-LaRoche AG, Basel, Switzerland) and all blots were reprobed using a human full-length cDNA probe for MHC class I antigens in the same manner to correct for possible variability in the amounts of RNA ( $20 \mu \mathrm{g} / \mathrm{lane})$ fixed to membranes, as described previously (4). No signal was obtained when hBST cells were stimulated with oxytocin $\left(10^{-8} \mathrm{M}\right)$ for $60 \mathrm{~min}$.

Receptor binding. $\mathrm{hBST}$ and $\mathrm{hBEP}$ were incubated for $3 \mathrm{~h}$ at $4^{\circ} \mathrm{C}$ in the presence of various concentrations (of ${ }^{125}$ I-ET $(0.025-5 \mathrm{nM}$; Anawa AG, Wangen, Switzerland) or ${ }^{125}$ I-epidermal growth factor (EGF) $(0.035-10 \mathrm{ng} / \mathrm{ml}$; Amersham, Zürich, Switzerland), and with or without the inclusion of $1 \mu \mathrm{M}$ unlabeled ET (porcine/human; Novabiochem AG, Läufelfingen, Switzerland) or $0.5 \mu \mathrm{g} / \mathrm{ml}$ unlabeled EGF (Collaborative Research Inc., Lexington, MA), respectively, for determination of nonspecific binding. Binding was terminated by repeated washing of cell layers in PBS containing $0.2 \%$ (wt/vol) BSA and subsequent lysis of cell layers in $1 \%$ (wt/vol) SDS as described previously (5). Radioactivity in cell lysates was quantitated and data from saturation binding profiles analyzed using the EBDA computer program.

S6-kinase activation and phosphoinositide metabolism. The activation of S6-kinase and subsequent phosphorylation assays were performed as detailed previously (5), where the time of incubation in the absence or presence of either EGF $\left(10^{-8} \mathrm{M}\right)$ or ET $\left(10^{-8} \mathrm{M}\right)$ was $15 \mathrm{~min}$ 

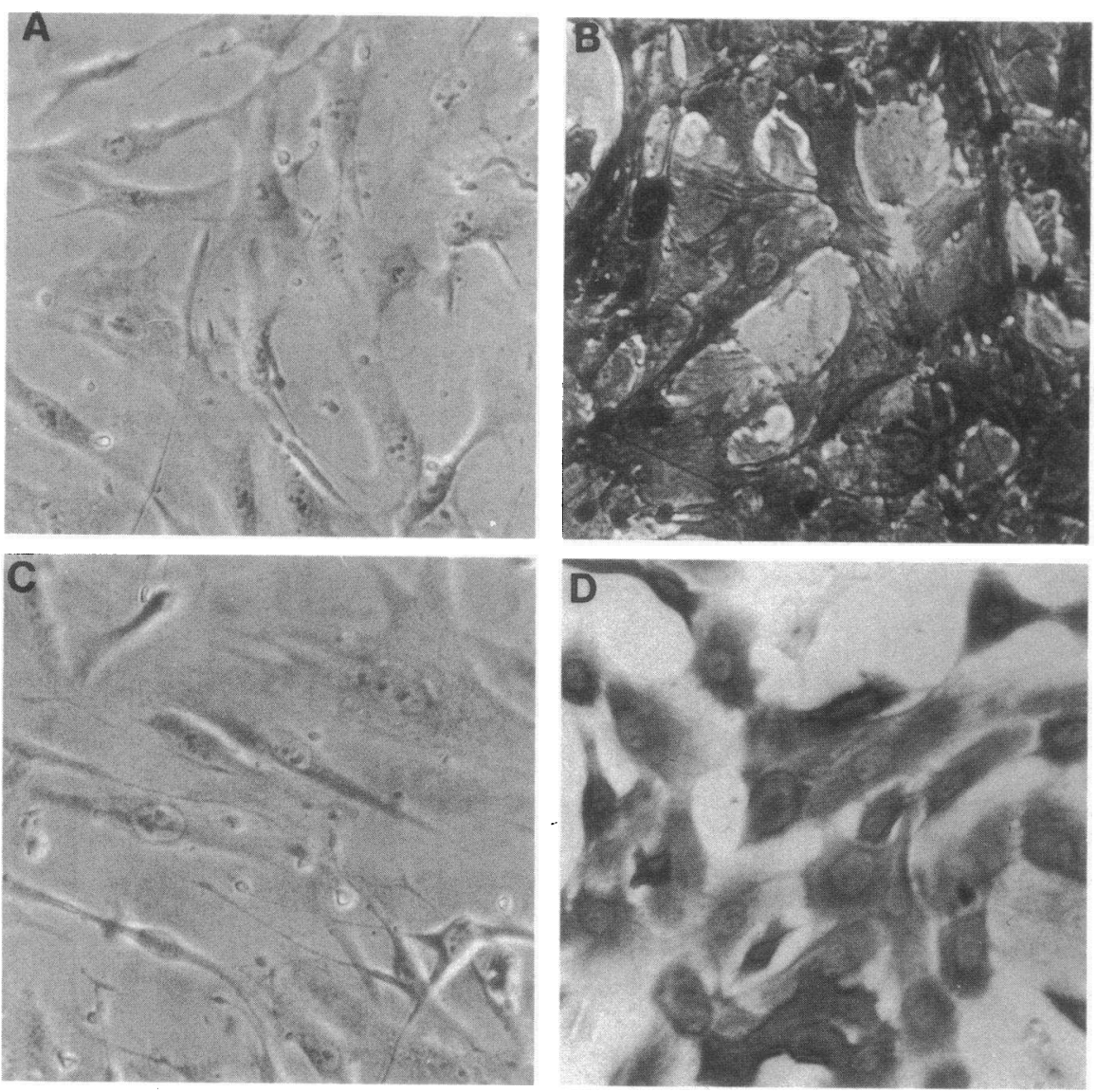

Figure 1. Immunocytochemical characterization of hBEP and hBST in culture. Phase contrast micrographs of Giemsastained, methanol-fixed hBST $(A$ and $C$ ), vascular smooth muscle cells $(B)$, and $\mathrm{hBEP}(D)$ after immunocytochemical procedures (see Methods). Cells were incubated with monoclonal antibodies raised against $\alpha$-smooth muscle actin in $A$ and $B$ and against epithelial-specific cytokeratins in $C$ and $D$. Magnification is $\sim \times 230$. at $37^{\circ} \mathrm{C}$. Phosphoinositide metabolism was studied in myo- $[3 \mathrm{H}]$ inositol prelabeled cells $(5 \mu \mathrm{Ci} / \mathrm{ml})$ for $48 \mathrm{~h}$ ) following procedures exactly as described previously (5). hBEP and hBST were exposed (in the presence of $10 \mathrm{mM} \mathrm{LiCl})$ to either EGF $\left(10^{-8} \mathrm{M}\right)$ or ET $\left(10^{-8} \mathrm{M}\right)$ for periods indicated in Results.

Measurement of ET production by $h B E P$ and $h B S T$. ET was measured in aliquots of medium overlay (see Results for experimental

Table I. ET and EGF Receptor Complements and Responsiveness in BEP and BST

\begin{tabular}{|c|c|c|c|c|c|c|}
\hline \multirow[b]{2}{*}{ Cell } & \multicolumn{2}{|c|}{ Receptor $\mathbf{B}_{\max }$} & \multicolumn{2}{|c|}{ S6-kinase response } & \multicolumn{2}{|c|}{$P_{3}$ response } \\
\hline & ET & EGF & ET & EGF & ET & EGF \\
\hline & \multicolumn{2}{|c|}{ sites $\times 10^{-3} /$ cell } & \multicolumn{2}{|c|}{ nmol PO $1 / 10^{6}$ cells } & \multicolumn{2}{|c|}{$\%$ control } \\
\hline hBEP & ND & $34 \pm 1.7$ & $0.28 \pm 0.10$ & $3.87 \pm 0.32$ & 100 & 160 \\
\hline hBST & $17 \pm 0.4$ & $15 \pm 0.8$ & $2.42 \pm 0.34$ & $4.28 \pm 0.27$ & 250 & 180 \\
\hline
\end{tabular}

Experimental procedures for ${ }^{125}$ I-ET and ${ }^{125}$ I-EGF binding (ND

= not detectable), activation of S6-kinase and phosphoinositide metabolism are described in Methods. Data are given either as mean $\pm \mathrm{SD}$ when at least three separate experiments were performed for each parameter, or as mean value from two separate experiments. The S6-kinase activation response was determined after exposure of cells to EGF or ET for $15 \mathrm{~min}$, and values given have been corrected for S6-kinase activity in control (without agonist) samples. The $\mathbf{I P}_{3}$ response was determined after exposure of $m y o-\left[{ }^{3} \mathrm{H}\right]$ inositol prelabeled cells to EGF or ET for $2 \mathrm{~min}$; values express the increase in $\left[{ }^{3} \mathrm{H}\right] \mathrm{IP}_{3}$ content as a percentage of that present $(100 \%)$ in control samples. protocol) using a radioimmunoassay kit according to the procedures detailed by the manufacturer (Peninsula Laboratories, Inc., Belmont, CA).

\section{Results and Discussion}

hBEP characterized by immunocytochemistry (Fig. 1) exhibited low constitutive expression of ET MRNA in culture, which was enhanced by their exposure to either transforming growth factor $\beta\left(\mathrm{TGF}_{\beta}\right)$ or physiological levels $(200 \mathrm{ng} / \mathrm{ml})$ of prolactin (Fig. 2). Such upregulation of ET mRNA expression has also been previously demonstrated in endothelial cells after exposure to thrombin (1) or $\mathrm{TGF}_{\beta}$ (6). hBST (see Fig. 1) isolated from the same tissue source as hBEP did not express detectable levels of ET mRNA in culture even when exposed to $\mathrm{TGF}_{\beta}$ or prolactin (Fig. 2). Oxytocin did not modulate ET gene expression in hBEP (Fig. 1), nor was a signal obtained when hBST were stimulated with oxytocin for $60 \mathrm{~min}$ (data not shown). Exposure of hBEP to prolactin resulted in a timedependent release of ET (immunoreactive) into medium overlay; plateau levels were obtained within $6 \mathrm{~h}$ and remained stable for up to $24 \mathrm{~h}$ of prolactin exposure (Fig. 3). Immunoreactive ET was not detectable in the conditioned medium of hBST (data not shown). Such data are in accord with the differential in ET mRNA expression responses (Fig. 2) between hBEP and hBST.

In opposition to the observation with respect to ET mRNA expression and secretion in these cells, hBST exhibited a timeand dose-dependent $\left(\mathrm{ED}_{50}=10^{-10} \mathrm{M}\right)$ stimulation of phos- 
hBEP
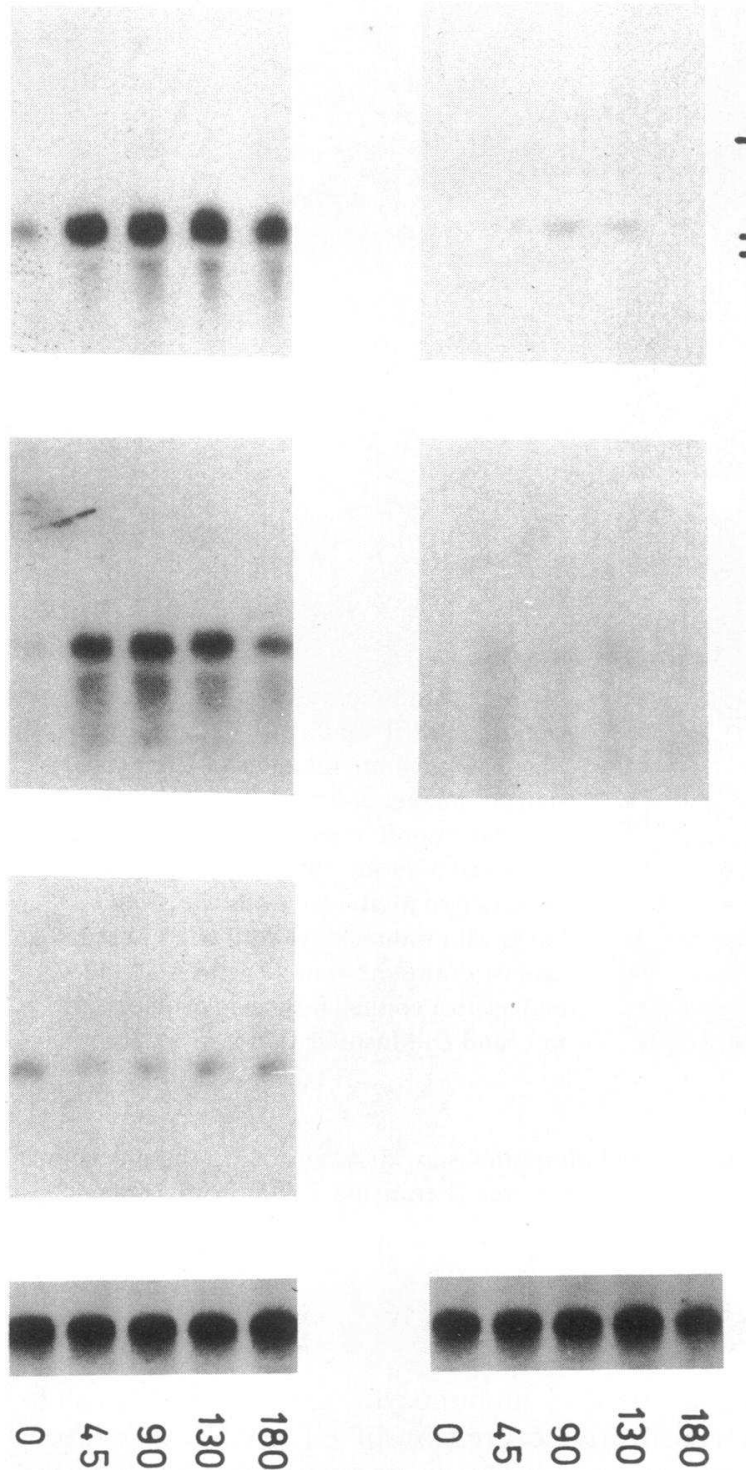

$$
\begin{aligned}
& -28 \mathrm{~s} \\
& =\begin{array}{l}
2.3 \mathrm{~kb} \\
18 \mathrm{~s}
\end{array}
\end{aligned}
$$

\section{Prolactin}

\section{Oxytocin}

Figure 2. Induction of ET $\mathrm{mRNA}$ in $\mathrm{hBEP}$ and hBST. Quiescent hBEP and hBST were stimulated with $\mathrm{TGF}_{\beta}(2 \mathrm{ng} / \mathrm{ml})$, prolactin $(200 \mathrm{ng} / \mathrm{ml})$, or oxytocin $\left(10^{-8} \mathrm{M}\right)$ for the indicated periods. Northern blot analysis was performed on $20-\mu \mathrm{g}$ amounts of total RNA extracted. ET-specific signals are indicated by a 2-3-kb mRNA species. MHC-specific hybridization is shown for prolactin-stimulated cells only. phoinositide catabolism when incubated with ET, whereas hBEP were absolutely unresponsive with respect to this parameter (Fig. 4). Kinetically the ET-induced generation of the water-soluble phosphoinositide metabolites (inositol phosphate [IP], inositol bisphosphate [ $\left.\mathrm{IP}_{2}\right]$, and inositol trisphosphate $\left.\left[\mathrm{IP}_{3}\right]\right)$ in $\mathrm{hBST}$ was both rapid and protracted as has been

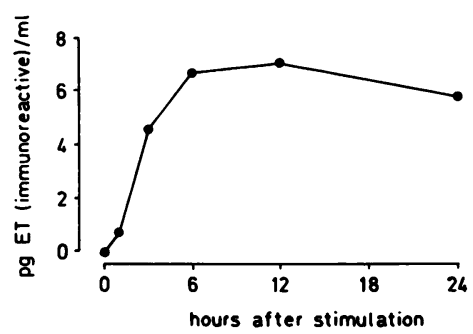

Figure 3. Measurement of ET production by hBEP. Immunoreactive ET was determined in aliquots of medium overlay after exposure of hBEP $\left(\sim 10^{5}\right.$ cells/ well) to prolactin $(200$ $\mathrm{ng} / \mathrm{ml}$ ) for the indicated periods. Data represent mean values of duplicate deter-

minations in triplicate samples; SD did not exceed 5\%. Immunoreactive ET was not detectable in conditioned medium of hBST. observed in studies on vascular smooth muscle cells $(7,8)$. In quiescent vascular smooth muscle cells ET is capable of activating S6-kinase, a response that is receptor dependent and coupled to phosphoinositide (and other) signal transduction mechanisms $(4,9,10)$. When hBST and hBEP were tested in this regard, only the stromal cultures exhibited an S6-kinase activation response to ET (Table I). Both cell types, however, exhibited equivalent responses to EGF in terms of both phosphoinositide catabolism and S6-kinase activation (Table I), which was compatible with their comparable ${ }^{125}$ I-EGF receptor complements (Table I). Such differential biochemical responsiveness to ET between hBST and hBEP cell types is indicative of differences in their ET receptor complement. Indeed, radioligand binding assays using ${ }^{125}$ I-ET demonstrated that hBST possessed specific high-affinity cell surface receptors for the ligand $\left(K_{d}=8.6 \times 10^{-11} \mathrm{M}\right)$, whereas no specific binding of radiolabeled ligand was detected for hBEP (Fig. 5 and Table I). 


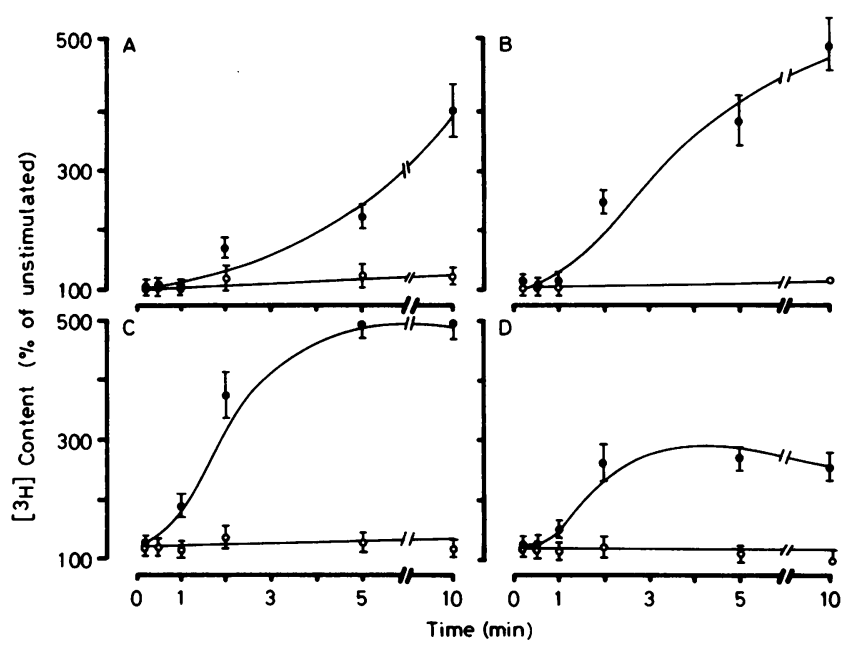

Figure 4. Metabolic response to ET. Time-dependent accumulation of IPs was determined in either hBST $(\bullet)$ or hBEP $(O)$ in response to ET $\left(10^{-8} \mathrm{M}\right)$. Tritium content of IPs in the aqueous phase of extracts was determined after separation of Gro-PIns (glycerophosphoinositol), IP, $\mathrm{IP}_{2}$, and $\mathrm{IP}_{3}$ by ion-exchange chomatography (4). Data (mean $\pm \mathrm{SD}, n=3$ ) express the percentage of initial tritium content (in absence of ET), which was arbitrarily taken as $100 \%$ for each of the inositol phosphates; data for Gro-PIns, IP, $\mathrm{IP}_{2}$, and $\mathrm{IP}_{3}$ are presented in $A, B, C$, and $D$, respectively. Typically, $100 \%$ values were $3,700 \pm 205,7,400 \pm 537,1,970 \pm 110$, and $2,120 \pm 160$ for GroPIns, IP, IP , and $\mathrm{IP}_{3}$, respectively. The concentration of ET required to half maximally stimulate IP production in hBST $\left(\mathrm{ED}_{50}=10^{-10}\right)$ was determined from experiments in which cells had been exposed to $10^{-11}-10^{6} \mathrm{M}$ ET for $3 \mathrm{~min}$ (profile not shown).

The data herein indicates that in vivo hBEP may be the principle producers of ET in breast tissues, and that the peptide released may target onto proximal hBST, which then mediate physiological responses to the initial stimulus. ET has previously been shown to modulate secretory processes both in the myocardium (stimulation of atrial naturetic peptide release [11] and the kidney (inhibition of renin release [12]), and

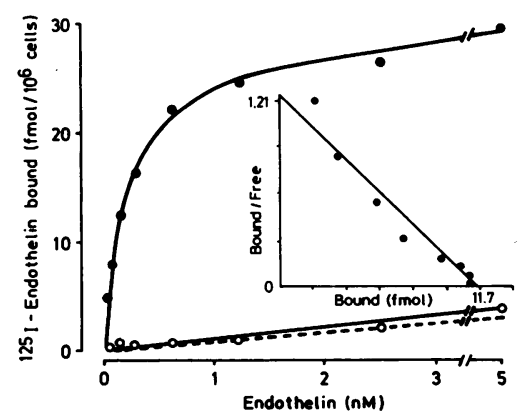

Figure 5. Saturable binding of ${ }^{125} \mathrm{I}$-ET to cultured hBST or hBEP cells. Binding assays were performed in 24 well multi-well dishes for $3 \mathrm{~h}$ at $4^{\circ} \mathrm{C}$ using the levels of radioligand indicated. A parallel series of dishes were also incubated with the radiolabeled ET in the presence of unlabeled ligand

$\left(10^{-6} \mathrm{M}\right)$ for determination of nonspecific binding $(---)$. Data for saturation profiles were obtained in experiments $(n=3)$ with different isolates of cells (hBST [๑] and hBEP [O] and after correction for differences in cell number are expressed as femtomoles bound $/ 10^{6}$ cells and represent the means of such values determined; SD of these values were $< \pm 0.5 \mathrm{fmol} / 10^{6}$ cells. The Scatchard analysis shown (inset) represents data from a typical saturation binding experiment performed with hBST $\left(3.2 \times 10^{5}\right.$ cells/well $)$ and a Hill plot coefficient of unity (data not shown) was also obtained in the same experiment. therefore the physiological importance of the present observation may relate to the process of milk secretion. Prolactin is necessary for the initiation and maintenance of lactation, and this process may be modified by other hormones such as oxytocin (for review, see reference 13). The induction of ET mRNA expression by breast epithelial cells exposed to prolactin and responsiveness of the underlying (in vivo) stromal cells to ET may function to facilitate a prolonged full contraction during the process of milk secretion.

\section{Acknowledgments}

We gratefully acknowledge the assistance given in the characterization of $h B S T$ and $h B E P$ by Dr. Petersen and Dr. van Deurs during the visit of Dr. Baley to the Panum Institute, Copenhagen, Denmark.

This study was funded by the Regionale Krebsliga Beider Basel, grants 5275 and 5275/2, and by the Roche Research Foundation.

\section{References}

1. Yanagisawa, M., H. Karihara, S. Kimura, Y. Tomobe, M. Kobayashi, Y. Mitsui, K. Goto, and T. Masaki. 1988. A novel potent vasoconstrictor peptide produced by vascular endothelial cells. Nature (Lond.). 332:411-415.

2. Yanagisawa, M., A. Inoue, T. Ishikawa, Y. Kasuqa, S. Kimura, S. Kumagaye, K. Nakajima, T. X. Watanabe, S. Sakaibara, K. Goto, and T. Masaki. 1988. Primary structure, synthesis and biological activity of rat endothelin, and endothelium derived vasoconstrictor peptide. Proc. Natl. Acad. Sci. USA. 85:6964-6967.

3. Petersen, O. W., and B. van Deurs. 1988. Growth factor control of myoepithelial cell differentiation in cultures of human mammary gland. Differentiation. 39:197-215.

4. Scott-Burden, T., T. J. Resink, A. W. A. Hahn, U. Baur, R. J. Box, and F. R. Bühler. 1989. Induction of growth related metabolism in human vascular smooth muscle cells by low density lipoprotein. $J$. Biol. Chem. 264:12582-12589.

5. Scott-Burden, T., T. J. Resink, U. Baur, M. Bürgin, and F. R. Bühler. 1989. Response to epidermal growth factor by cultured smooth muscle cells from hypertensive rats. Hypertension (Dallas). 13:295-304.

6. Kurihara, H., M. Yoshizumi, T. Sugiyama, F. Takaku, M. Yanagisawa, T. Masaki, M. Hamaoki, H. Kato, and Y. Yazaki. 1989. Transforming growth factor-beta stimulates the expression of endothelin mRNA by vascular endothelial cells. Biochem. Biophys. Res. Commun. 159:1435-1440.

7. Resink, T. J., T. Scott-Burden, and F. R. Bühler. 1989. Endothelin stimulates phospholipase $C$ in cultured vascular smooth muscle cells. Biochem. Biophys. Res. Commun. 157:1360-1368.

8. Resink, T. J., T. Scott-Burden, and F. R. Bühler. 1989. Activation of phospholipase $A_{2}$ by endothelin in cultured vascular smooth muscle cells. Biochem. Biophys. Res. Commun. 158:279-286.

9. Resink, T. J., T. Scott-Burden, and F. R. Bühler. 1989. Responses to endothelin in cultured vascular smooth muscle cells. $A d v$. Microcirc. In press.

10. Novak-Hofer, I., and G. Thomas. 1985. Epidermal growth factor mediated activation of an S6-kinase in swiss mouse 3T3 cells. $J$. Biol. Chem. 260:10314-10319.

11. Fukuda, Y., Y. Hirata, H. Yoshimi, T. Kojima, Y. Kobayashi, M. Yanagisawa, and T. Masaki. 1988. Endothelin is a potent secretagogue for atrial natriuretic peptide in cultured rat atrial myocytes. Biochem. Biophys. Res. Commun. 155:167-172.

12. Rakugi, H., M. Nakamaru, H. Saito, H. Higaki, and T. Ogihara. 1988. Endothelin inhibits renin release from isolated rat glomeruli. Biochem. Biophys. Res. Commun. 155:1244-1247.

13. Whitworth, N. S. 1988. Lactation in humans. Psychoneuroendocrinology. 13:171-188. 